DOI: $10.2478 / \mathrm{v} 10047-011-0017-6$

PHYSICAL AND TECHNICAL PROBLEMS OF ENERGETICS

\title{
METHOD OF POWER SYSTEM SUISTANABLE DEVELOPMENT OPTIMIZATION IN LIBERALIZED MARKET CONDITIONS
}

\author{
M. Turcik, I. Oleinikova, Z. Krishans
}

Laboratory for Power System Mathematical Modelling, Institute of Physical Energetics, 21 Aizkraukles Str., Riga, LV-1006, LATVIA

The paper is focused on the development of the Baltic Sea region taking into account the new EU energy policy. The authors elucidate the current situation and the power system infrastructure projects of the region. For the economic analysis and optimization of the development plans a method is proposed that takes into account the outlooks for upcoming 20-50 years and the initial information uncertainty. The method makes possible estimation of the technically-economic state, including market conditions, for a given power system. market.

Key words: Power system management, optimization methods, electricity

\section{INTRODUCTION}

The management of power system (PS) sustainable development is a sophisticated activity characterized by uncertainty in the decision-making process. Furthermore, new environment and requirements defined by the liberalized market should be taken into account as well. The development problems of existing systems are becoming ever more complicated. Only by applying special methods it is possible to reach the best results. For this purpose, in this paper a method for PS sustainable development optimization is proposed.

In a process of planning and decision-making, final decisions are made based on the evaluation of more or less credible information. The PS is a highly complicated system, with various interdependences between its elements. For selection of the best possible option in a particular situation, the development optimization methods present an inestimable instrument.

The results of these methods determine not only what, but also when a development action should be performed. Optimization methods under liberalized market conditions have significant impact on the PS development, planning and restructuring process.

\section{POWER SYSTEM DEVELOPMENT IN BALTIC STATES}

Inter-State transmission lines were predominantly constructed to maintain stability and increase security of interconnected PSs. However, the new wellfunctioning electricity market, with its competitive environment, considerably depends on the possibilities to transmit power from producers to consumers. Therefore, liberalization of electricity markets has enhanced the importance of transmission capacity sufficiency on internal lines and of cross-border connections 
due to the growth in trades and exchanges between countries. Benefits for involved countries are derived from cross-border trade and transit of electricity, which improves the usage of the transmission system and, in many cases, requires the strengthening of transmission capability.

The PSs of Baltic States (Estonia-Latvia-Lithuania) are working synchronously with those of Belarus and Russia. The utilization capacities of cross-border lines strongly depend on the internal transmission capability of a respective country. Due to this reason many projects for internal grid reinforcement have been implemented.

The Baltic Energy Market Interconnection Plan (BEMIP), approved by the European Commission (EC), provides implementation of several vital energy projects in the Baltic States with a view to avert their energy isolation. Several of the proposed BEMIP infrastructure projects are included into the European Economic Recovery Plan (EERP). This potentially means more than half a billion euros as additional support for the mentioned projects in our region [1]. The tendencies observed in the development of Baltic PSs are illustrated by Table 1 .

Table 1

Tendencies of Power System development in the Baltics

\begin{tabular}{|l|c|c|c|}
\hline \multicolumn{1}{|c|}{ Project } & Capacity, MW & Investments, mln. $€$ & Final date \\
\hline Estlink II link & 650 & 280 & 2014 \\
\hline Power plant in Latvia & 400 & 300 & 2013 \\
\hline NordBalt link & 1000 & 630 & 2017 \\
\hline NPP in Lithuania & 3200 & 8000 & $2020-2025$ \\
\hline Lithuania-Poland link & 1000 & 1110 & 2020 \\
\hline
\end{tabular}

The future position of individual States on the global market scale will be to a great extent determined by the power productivity. The sufficiency/deficiency in electricity production, the structure (diversification) of power sources, and the capabilities of power lines have a considerable impact both on the cross-border and the internal market activity. The current state of power production in Baltic is shown in Fig. 1 [2].

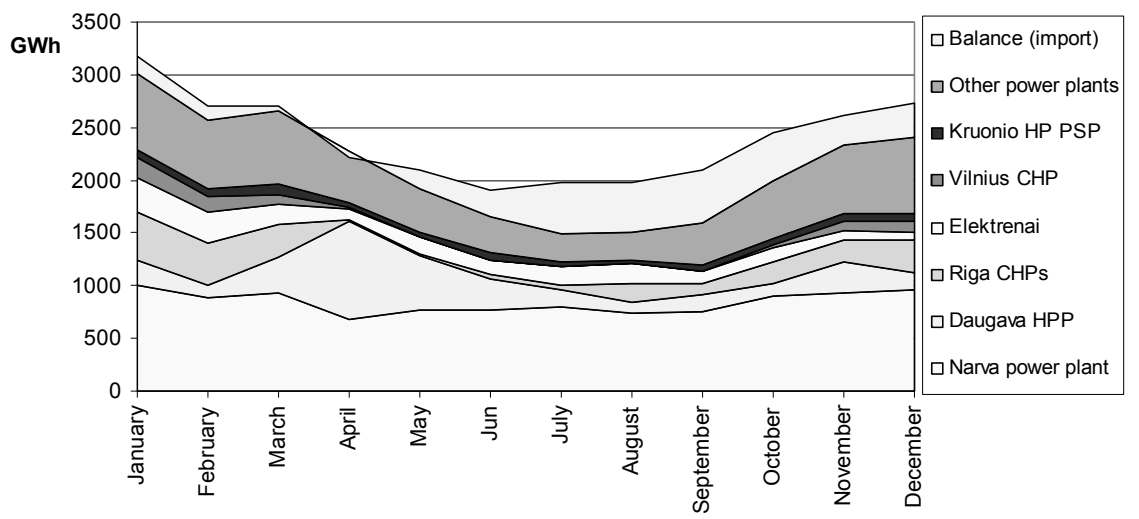

Fig. 1. Power production and balance, GWh (Baltic, 2010) [2]. 
The major projects of new generating capacities in Latvia for the upcoming years are represented by a $400 \mathrm{MW}$ combined heat-and-power plant and Wind Park in Kurzeme (west coast). The Latvian TSO has officially registered requests for construction of wind power plants (WPPs) in Kurzeme, on land and offshore, with the total installed power up to $2000 \mathrm{MW}$. However, the existing $110 \mathrm{kV}$ transmission network in Kurzeme allows connection of only limited WPP capacities, up to 220 MW [3, 4].

Recent forecast of Estonian TSO (Elering) for 15 years (since 2010) shows that by 2017 the power generation in Estonia will be radically reduced. In particular, the generation deficit estimated for the period 2016-2017 is about $900 \mathrm{MW}$, and for the period 2020-2025 - about 1400 MW. Substantial decrease in the Estonian power production will cause decommissioning of six blocks at the Narva Power Plants in 2016 (the complex Narva covers about 95\% of the total production in Estonia), closure of the Ahtme station and conservation of blocks at the Iru and Balti Power Plants [5, 6]. The most important projects for security supply in Estonia are represented by the second Finland-Estonia interconnection with the nominal transmission capacity of $650 \mathrm{MW}$, and a new power plant as disturbance reserve $(250 \mathrm{MW})$. Commissioning of the projects is expected by the end of 2014 and 2015, respectively. According to the Estonian National Renewable Energy Action Plan, about 900 MW of installed wind power is foreseen by 2020.

The Lithuanian strategic projects of PS development envisage implementation of a $400 \mathrm{kV}$ double-circuit line Lithuania-Poland (LitPol Link). The project is to be realized in two stages, with commissioning in 2015 and 2020, respectively. Besides, in 2015 putting into operation of a $700 \mathrm{MW}$ capacity HVDC submarine cable between Lithuania and Sweden (NordBalt) is expected.

The Lithuanian interconnection projects are very important for ensuring security of supply both for Lithuania and for the whole Baltic region. Their implementation would also secure fuel diversification in Lithuania [7].

\section{DEVELOPMENT OF THE BALTIC ELECTRICITY MARKET}

Further development of the Baltic electricity market is conditioned by completion of the infrastructure projects and amendments in Energy Legislation. Closer integration with the Nordic (Finland, Sweden, Denmark, and Norway) electricity market will increase the reliability of supply in the Baltic; besides, it will allow the market participants to take advantages of a wider common electricity market.

The primary function of a physical electricity market is to establish balance between supply and demand. In a high-quality handle this task is an extremely important, because power shortages entail very substantial socio-economic costs. A well-functioning power market ensures that electricity is generated wherever the cost of generation is the lowest at any time of the day. Increases in demand will be balanced by more expensive generating modes. This also gives the market an indication of what it would take to establish a new generating capacity. In socioeconomic terms, this provides a clear indication of the costs the society would have to bear in order to incorporate a new output in the system. Where commercial considerations are concerned, the generators will receive a good indication of where the break-even point lies for developing a new generating capacity. The 
Nord Pool's physical market also ensures that power supply and demand are balanced right up to one hour before the time of consumption.

The structure of the Latvian electricity market is shown in Fig. 2.

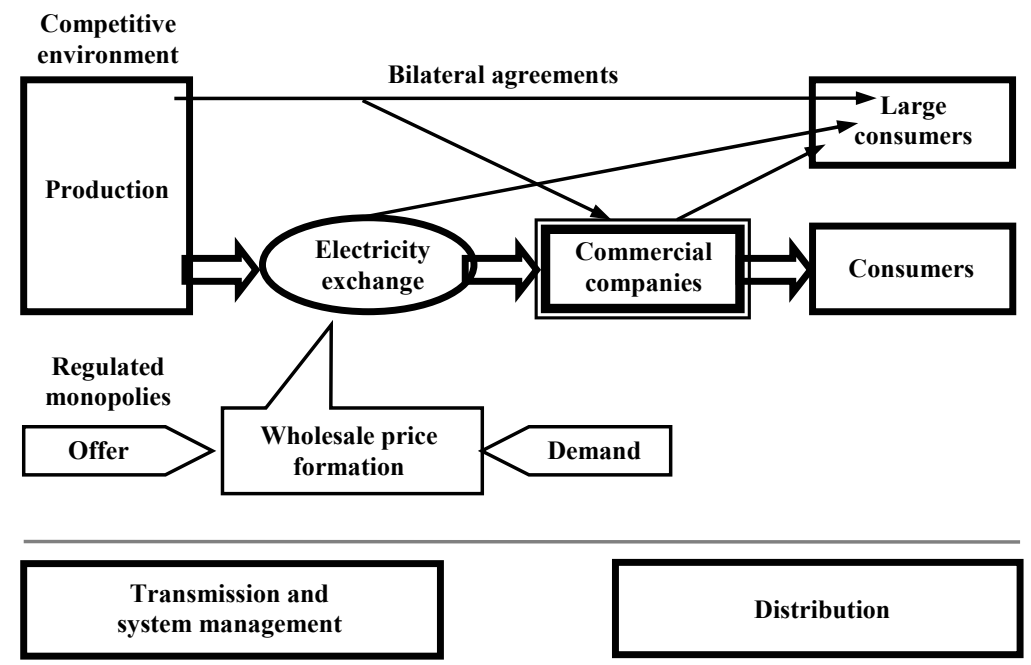

Fig. 2. Structure of the Latvian electricity market.

The strategic objective of Baltic power systems is to integrate local power markets into the European power market area and to increase the security of supply in the whole region. The goal of Nordic TSOs is to promote the development of the electricity market and enhance the coordination of planned interconnections. By reaching these goals, the market of the entire Baltic Sea region would become more closely integrated into the common European electricity market. This co-operation is being launched to establish a coordinated and transparent planning relationship between the former NORDEL, BALTSO and UCTE (Polish TSO), while also developing a coordinated extension plan of interconnections from the Baltic towards the NORDEL area and Poland in order to satisfy transmission needs between them.

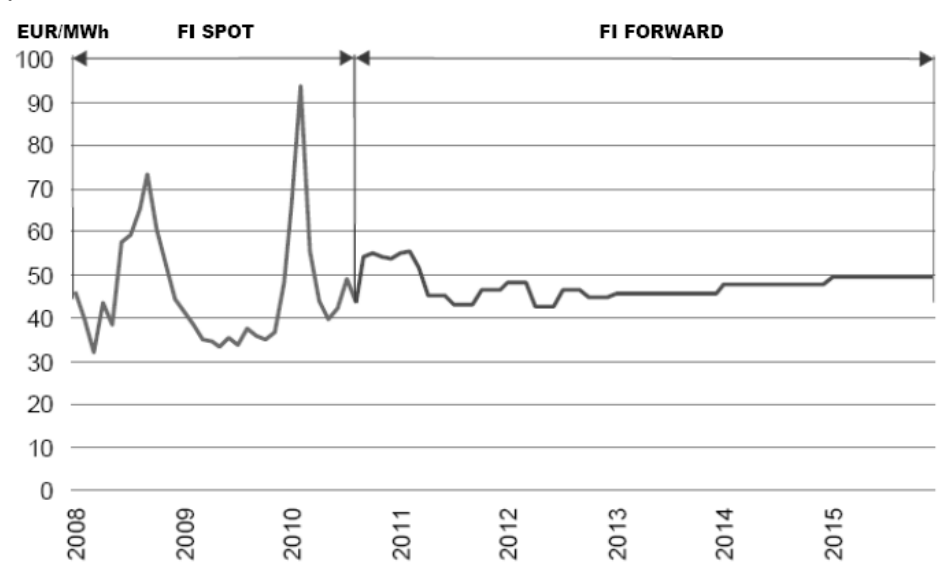

Fig. 3. Nord Pool Electricity Market price trend. 
Due to closer integration of Baltic with Nordic countries in the future and to the planned extension of Nord Pool Spot (NPS) power exchange (NORDEL) operation in Baltic States, the expected (forecasted) trend of the NPS spot price provides substantial information for market participants in Baltic (see Fig. 3) [8].

Effective management of the development projects requires creation of a long-term D-plan for developing interconnections between the regions, generating structures and other PS technical infrastructure elements.

An appropriate tool to be used in the methods for PS sustainable development optimization is described below.

\section{CRITERIA FOR OPTIMIZATION \\ OF POWER SYSTEM SUSTAINABLE DEVELOPMENT}

To effectively manage the major projects planned for the next years the criteria of optimization are to be employed. First, it is necessary to determine the objective function for a relevant development action (D-action) and a power system's limitations. Usually, for the development optimization tasks multiple criteria are defined (see Fig. 4).

The basis for the effectiveness of a development plan (D-plan) is the preponderance of benefits over the used resources. For evaluation it is therefore necessary to describe the investments and benefits in the monetary terms.

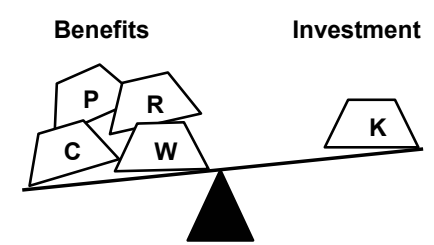

Fig. 4. Estimation of D-actions: Operation and maintenance costs reduction (C); Overload reduction (P); New consumers connection (W); Power supply security improvement (R); Investment (K).

The D-actions should be estimated applying the method named "economic life cycle concept" [9].

The major economic efficiency indices for a $\mathrm{D}$-action are:

- Net Present Value (if NPV $>0$ a D-action is economically effective);

- Internal Rate of Return (IRR $>10 \%$ );

- Pay-Back Period (PB - the least possible).

In order to estimate these indices in the preliminary stage of a D-action, the cash flow should be calculated for the whole economic life-cycle of a power system. If the cash flow is calculated including the D-action and excluding it, then the ratios of economic efficiency of this D-action can be estimated. Specific criteria for our task are presented in Fig. 5.

As concerns technical criteria, they depend on a specific system. In dynamic models for development optimization, limitation on technical parameters is observed not by strict constraint values but via the so-called fuzzy constraint method [9].

Applying the mentioned method, the objective function is supplemented by additional criteria (i.e. penalty functions). 


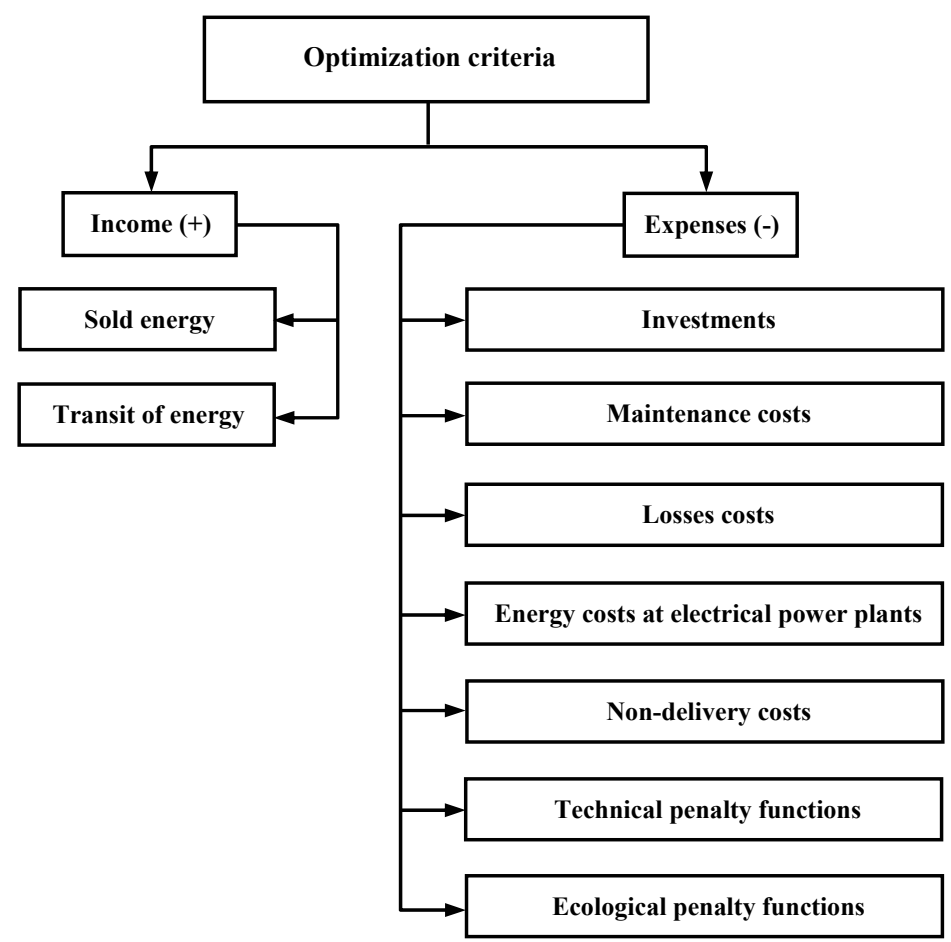

Fig. 5. Structural scheme of optimization criteria.

The penalty function value within limits is not high, but it increases considerably with distance (see Fig. 6).

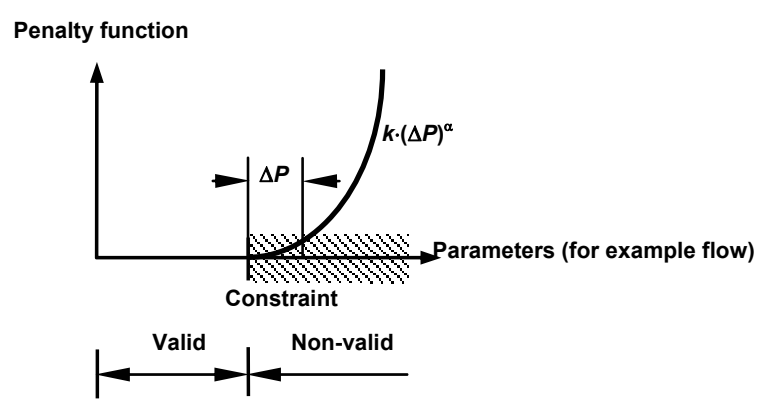

Fig. 6. Principle of the fuzzy constraint method.

Application of the fuzzy constraint method gives an extra opportunity to speed up the optimization process.

\section{POWER SYSTEM DEVELOPMENT OPTIMIZATION METHOD}

To apply the proposed method it is necessary to use the information technology meant for the sustainable development management of power systems. The IT structure is displayed in Fig. 7.

The module Actions forms the development model used to determine the optimal D-plan by the estimation method (Plans) as well as by the optimal initial state (OIS) method (optimization). 


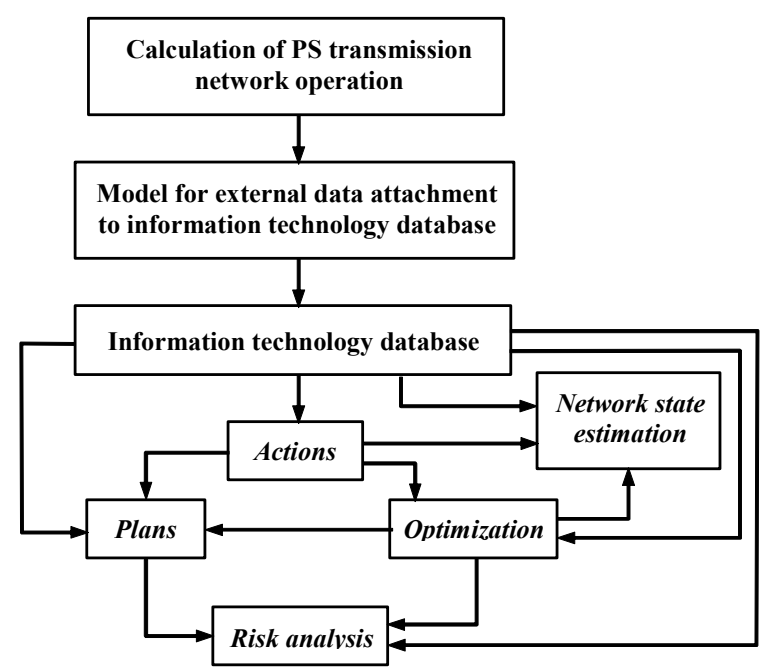

Fig. 7. IT structure of sustainable PS development optimization.

The final calculation realized in the module Network state estimation includes: 1) the load flow calculation, 2) the switchgear reliability estimation, 3) the network reliability estimation, 4) the energy balance calculation for each state [9].

The main criterion for a PS D-plan is optimization management of the objective function, which includes and integrates technical, economic, reliability, ecological, etc., factors. The objective function is calculated by the formula:

$$
F(T, g)=\sum_{t=1}^{T} F(e(t))
$$

where: $t \quad-$ development step serial number;

$T \quad-$ number of development steps in the estimation period;

$F(e(t)) \quad-$ system quality criterion in development step $t$ and development state $e(t)$;

$g \quad-$ development plan $e(1), e(2), \ldots, e(t), \ldots, e(T)$.

For the estimation period of PS sustainable development optimization, $T$ should be assumed longer than the economic life cycle period (see Fig. 8). The relevant information for this period is uncertain; therefore, the decisions made have to be specified regularly.

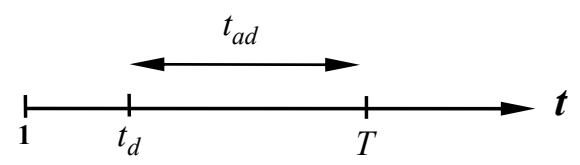

Fig. 8. Estimation $(T)$, decision making $\left(t_{d}\right)$ and adaptation $\left(t_{a d}\right)$ periods.

The objective function is the sum from $F(e(t))$ for $t=1,2,3, \ldots, T$; therefore, for optimization method the basic principle of dynamic programming (method of optimal initial states) can be used. 
The target of the PS development optimization is to determine and identify an admissible D-plan in which the maximally reduced quality criterion of a system's development (i.e. objective function) is to be met in $T$ development steps.

Such a development plan will be marked $\operatorname{optg}[T, E(T)]$, with the respective objective function defined as:

$$
f[T, E(T)]=\max _{g \in G} F(g) .
$$

In real tasks, the calculation of all possible development plans could be enormously protracted. Therefore, the optimization method does not cover analysis of all development plans $g \in G$. The reduction process is calculated by the module Plans.

A set of comparable development plans are obtained by optimizing the technical system considered and using the average data (i.e. the basic forecast). As a result of optimization, up to 10 best competitive development plans are obtained by module Optimization.

Further on, a system analyst, sharing his experience, may reduce or supplement this set.

The risk analysis is employed for selection of the optimal development plan, enabling such selection under information uncertainty conditions (by module Risk Analysis). For the tasks of PS sustainable development the most appropriate is the minimal-maximal risk:

$$
\min _{j \in V} R(j)_{\max }=\min _{j \in v} \max _{i \in \mu}(F(j, i)-F(i)),
$$

where: $F(i) \quad-$ maximal objective function value for forecast $i$;

$F(j, i) \quad-$ objective function for development plan $j$ in forecast $i$;

$i \quad-$ serial number of forecast $i$;

$j \quad-\quad$ serial number of development plan;

$\mu \quad-$ set of forecasts;

$v \quad-$ set of development plans.

The proposed method for PS development optimization involves sophisticated, interactive and computer-aided techniques for decision making. These can alleviate complexity of the problems that would be otherwise difficult to handle. The knowledge based on this method can support the decision makers in selecting criteria, actions, plans, etc., thus making the power system planning simple and more effective.

\section{CONCLUSIONS}

The proposed method of Power System Sustainable Development Optimization in Liberalized Market Conditions could be used for PS sustainable development management. It is focused on the improvement of investment effectiveness and substantiation of the actions towards prime cost reductions in high-voltage networks. Also, this method could be applied for development planning in network 
utilities, project design organizations, educational and scientific research institutions. This method will help to perform economic analysis and optimization observing the development perspective (20-50 years) and the initial information uncertainty: in particular, to estimate the technical economic state of a given system including identification of the bottle-neck problems, to determine whether the system is economically effective in order to construct new power plants (with what capacity and where), reconstruct or upgrade the existing power plants, erect new substations and electric transmission power lines, dismantle or restructure substations and electric transmission lines, etc..

\title{
REFERENCES
}

1. Baltic Energy Market Interconnection Plan. (25 Nov. 2009). Final Report of the High Level Group (Vilnius).

2. Bariss, U. (11 May, 2011). Development perspectives of electricity market in Latvia and Baltics. Riga (in Latvian).

3. Baltic Regional Group Annual Report 2009. (2010).

4. The Kurzeme Ring. Latvenergo (official information). http://www.latvenergo.lv.

5. Estonian Energy in Figures, 2007. (2008). Estonian Ministry of Economic Affairs and Communications. http://www.m-km.ee/public/esto-nian_energy_in_figures.pdf.

6. Elering: Company Report 2010. http://www.businessrevi-eweurope.eu/companyeports/elering-oue.

7. European Network of Transmission System Operators for Electricity. (2010). Scenario Outlook and System Adequacy Forecast 2011-2025. Brussels: ENTSO-E AISBL .

8. Bariss, U. (21 Sept., 2010). Latvian investments in energy sector: the desired and real. (in Latvian).

9. Krishans, Z., Mutule, A., Merkuryev, Y., \& Oleinikova, I. (2011). Dynamic Management of Sustainable Development: Methods for Large Technical Systems. Berlin: Springer.

\section{ENERGOSISTĒMU ILGTSPĒJĪGAS ATTĪSTĪBAS OPTIMIZĀCIJAS METODE BRĪVA ELEKTROENERĢIJAS TIRGUS APSTĀKḶOS}

\author{
M. Turčik, I. Oḷeinikikova, Z. Krišāns
}

\section{Kopsavilkums}

Rakstā galvenā uzman̄ība veltīta Baltijas valstu energosistēmu attīstības tendencēm, to infrastruktūras uzlabošanai un enerğijas piegādes diversifikācijai. Visi šie projekti ir pārstāvēti jaunajā ES energoapgādes un solidaritātes rīcības plānā, kurā ir apskatīta arī Baltijas valstu energosistēmu starpsavienojumu saišu izveide (BEMIP).

Baltijas valstu integrācija ES energosistēmā ir galvenais mērḳis nākotnes stabilitātei un ekonomiskai izaugsmei. Plāns paredz būtiskus ieguldījumus jaunu elektroenerǵijas ražošanas jaudu un Baltijas reǵiona starpsavienojumu saišu ar Skandināvijas valstīm un Eiropu attīstībā. Šajā rakstā ir aprakstīta energosistēmas ilgtspējīgas attīstības metode liberalizēta tirgus apstākḷos, kura tiks izmantota energosistēmas ilgtspējīgai attīstībai. Tās mērķis ir investīciju efektivitātes uzlabošana 
un pārvades tīklu pašizmaksu samazināšanas pasākumu pamatojums. Piedāvāto metodi var izmantot arī attīstības plānošanai tīklu uzņēmumos, projektēšanas organizācijās, izglītības un zinātniskās pētniecības iestādēs. Metode veiks ekonomisko analīzi un optimizāciju, ievērojot attīstības perspektīvas (20-50 gadi) un sākotnējās informācijas nenoteiktību, novērtējot konkrētās sistēmas tehnisko ekonomisko stāvokli, ņemot vērā starpsavienojumu saišu šķēlumus.

03.06.2011. 